\title{
Should eGFR and Albuminuria Be Added to the Framingham Risk Score? Chronic Kidney Disease and Cardiovascular Disease Risk Prediction
}

\author{
Alex Chang $^{a}$ Holly Kramer ${ }^{a, b}$ \\ a Division of Nephrology and Hypertension, Department of Medicine and ${ }^{b}$ Department of Preventive Medicine and \\ Epidemiology, Loyola University Medical Center, Maywood, III., USA
}

\section{Key Words}

Cystatin $C \cdot$ Creatinine $\cdot$ Chronic kidney disease $\cdot$

Cardiovascular disease $\cdot$ Risk prediction

\begin{abstract}
Presence of chronic kidney disease (CKD) defined as decreased glomerular filtration rate (GFR) and/or increased urine albumin excretion is associated with heightened risk of cardiovascular disease (CVD) and all-cause as well as CVD mortality. Although CKD is strongly linked with CVD, it remains undetermined whether this strong association is simply due to shared CVD risk factors or unique traits consequential to CKD. The probability of future CVD events can be estimated with reasonable accuracy using the Framingham equation which was derived from the Framingham study, a community-based cohort of 5,209 white adults aged 30-62 years who were first examined in 1948. Efforts to capture excess CVD risk associated with CKD have been evaluated by adding estimated GFR, cystatin C, serum creatinine and measures of urinary albumin excretion to the Framingham equation which is based on traditional cardiovascular risk factors. Although decreased GFR and increased urine albumin excretion are consistently associated with cardiovascular outcomes, the addition of these factors to the Framingham equation has not been shown to substantially improve overall CVD risk prediction in populations not enriched with CKD.
\end{abstract}

Moreover, the Framingham equation itself underpredicts cardiovascular events among adults with stage 3 and 4 CKD without clinical CVD. Given the poor performance of the Framingham equation in adults with CKD, future studies should explore risk equations which include traditional CVD risk factors and the unique comorbidities associated with CKD for prediction of cardiovascular events in adults with CKD.

Copyright $\odot 2011$ S. Karger AG, Basel

\section{Introduction}

Chronic kidney disease (CKD), defined as an estimated glomerular filtration rate (eGFr) $<60$ or a spot urine albumin/creatinine ratio $\geq 30 \mathrm{mg} / \mathrm{g}$, affects roughly 1 in every 7 adults with the majority of CKD cases existing among adults at age $>50$ years [1]. The presence of CKD heightens an individual's risk for cardiovascular disease (CVD), death from cardiovascular disease (CVD) and all-cause mortality [2-12], and this risk increases once eGFR declines below a threshold of $45-60 \mathrm{ml} / \mathrm{min} / 1.73$ $\mathrm{m}^{2}$ [12]. Increased levels of urinary albumin excretion confer increased CVD risk across all ranges of GFR, regardless of how urine albumin excretion is assessed [for example, spot urine albumin/creatinine ratios (ACR), timed urine collections or urine dipstick measurements]

\section{KARGER}

Fax +4161306 1234 E-Mail karger@karger.ch www.karger.com

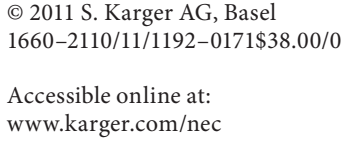

Holly Kramer, MD, MPH

Loyola University Medical Center

Department of Preventive Medicine

2160 First Avenue, Maywood, IL 60153 (USA)

Tel. +1 708327 9039, E-Mail Hkramer@lumc.edu 
$[4,10,12-16]$. It is important to note that low muscle mass may confound these associations as low urine creatinine excretion is independently associated with increased risk of CVD and mortality [17]. Likewise, muscle wasting, reflected as low serum creatinine, can result in falsely high eGFR.

The probability of future CVD can be estimated with reasonable accuracy in many different populations using equations derived from the Framingham study, which do not include measures of CKD [18-20]. Due to the strong association between CKD and CVD, it may seem intuitive to utilize CKD measures for CVD risk prediction. In this review, we discuss the association between CKD and CVD (events consequential to disease of coronary or peripheral arteries or veins, including coronary heart disease, CHD) and CHD (events consequential to disease of coronary circulation only), summarize studies which have explored the accuracy of the Framingham equation to predict CVD events in populations with CKD, and evaluate efforts to improve CVD risk prediction utilizing CKD measures.

\section{Decreased GFR as an Independent Risk Factor for CVD}

The relationship between decreased GFR and CVD has been examined in numerous studies with the majority of studies involving high-risk populations (individuals with hypertension, heart failure, coronary artery disease, acute coronary syndrome, coronary artery bypass surgery, diabetes or age $>65$ years) $[7,16,21-23]$ or lowrisk populations $[2-4,7-9,11,12,24]$ demonstrating increased CVD risk with decreased eGFR. The largest single study to date includes over 1.1 million adults enrolled in the Kaiser Permanente health plan with assessment of traditional CVD risk factors (blood pressure, lipids and smoking), serum creatinine and urinalysis [11]. GFR was estimated using the Modification of Diet in Renal Disease formula. Over a median follow-up of 2.4 years, a graded and inverse association was noted between eGFR and CVD events, hospitalizations and mortality, with 40, 100 and $180 \%$ higher adjusted risk in groups with eGFR $45-59,30-44$, and $15-29 \mathrm{ml} / \mathrm{min} / 1.73 \mathrm{~m}^{2}$, respectively, compared to the groups with eGFR $\geq 60 \mathrm{ml} / \mathrm{min} / 1.73 \mathrm{~m}^{2}$. These findings were supported by a recent collaborative meta-analysis that pooled data from 21 general population cohort studies to assess the relationship between CKD measures and CVD mortality [12].

\section{ACR as an Independent Risk Factor for Mortality}

Higher ACR levels are directly associated with CVD outcomes and this risk begins at ACR levels below clinical thresholds for microalbuminuria (ACR $\geq 30-299 \mathrm{mg} / \mathrm{g}$ ) [25]. The aforementioned CKD Prognosis Consortium meta-analysis included data from 14 studies and 105,872 individuals with baseline urine ACR measurements [12]. A linear association between ACR and CVD mortality was noted when ACR was examined on a logarithmic scale, and this heightened risk began with ACR levels $>10$ $\mathrm{mg} / \mathrm{g}$. Similar findings were noted when the analysis was limited to studies which used trace or $\geq 1+$ urine dipstick results as the measure of increased urine albumin excretion [12]. While most previous studies focused solely on decreased GFR or increased urine albumin excretion as a predictor of CVD risk, this meta-analysis highlighted the importance of examining eGFR and urine albumin excretion concurrently for CVD mortality risk [12]. Associations between CVD mortality and eGFR $<60 \mathrm{ml} /$ $\mathrm{min} / 1.73 \mathrm{~m}^{2}$ appeared similar across all levels of ACR. Likewise, CVD mortality risk associated with increased levels of ACR and positive urine dipstick measurements was independent of eGFR level. Thus, the effects of decreased eGFR and increased ACR are multiplicative for CVD mortality risk [12]. Individuals with eGFR of $80 \mathrm{ml} /$ $\mathrm{min} / 1.73 \mathrm{~m}^{2}$ and ACR $>300 \mathrm{mg} / \mathrm{g}$ (stage $2 \mathrm{CKD}$ ) carry twice the risk of either death or myocardial infarction (MI) compared to individuals with eGFR $50 \mathrm{ml} / \mathrm{min} /$ $1.73 \mathrm{~m}^{2}$ and an ACR $<30 \mathrm{mg} / \mathrm{g}$ (stage 3 CKD) [12]

\section{What Factors Account for Excess CVD Risk Associated with CKD?}

The increased CVD risk associated with CKD may simply reflect a longer duration or severity of traditional CVD risk factors such as hypertension, diabetes and dyslipidemia [5]. This is supported by a graded association between levels of subclinical cardiovascular disease and ACR among adults without established CVD [26]. Prevalence of left ventricular hypertrophy $(\mathrm{LVH})$ is inversely related to eGFR and approximately 3 of 4 patients with stage $5 \mathrm{CKD}$ have $\mathrm{LVH}$ at the time of dialysis initiation $[27,28]$. Many posit that nontraditional risk factors consequential to CKD such as anemia, hyperphosphatemia, increased fibroblast growth factor-23 levels, inflammation and unmeasured uremic factors account for at least some of the excess cardiovascular risk [2, 29-33]. However, to date, no studies have demonstrated that these 
unique factors improve the classification of CVD risk in adults with CKD above and beyond traditional cardiovascular risk factors.

\section{Framingham Risk Score}

Various risk scores predicting coronary heart disease (CHD), meaning events consequential to disease affecting the coronary circulation, have been derived using data from the Framingham Heart Study, a communitybased cohort of 5,209 white adults aged 30-62 years living in the Boston suburb of Framingham who were first examined in 1948 [34]. The inclusion of several variables into a risk prediction model enhances the predictive ability for CHD, a complex disease consequential to the interactions between multiple risk factors. In 1976, Kannel [35] first created a CHD risk score, which incorporated age, gender, smoking, systolic blood pressure, total cholesterol, electrocardiogram evidence of $\mathrm{LVH}$, and diabetes. Subsequently, several iterations of this $\mathrm{CHD}$ risk score have been validated in differing populations [35]. A sex-specific CHD risk prediction model based on the Fifth Joint National Committee on Hypertension blood pressure categories and National Cholesterol Education Program Adult Treatment Panel (NCEP-ATP) II cholesterol categories was created in 1998 [20]. This risk model predicts 'hard' CHD (MI and CHD death) using age, sex, blood pressure, total cholesterol, low-density cholesterol, high-density cholesterol, smoking status and diabetes, and has been incorporated into the NCEP-ATP III guidelines, in which lipid-lowering therapy is based on estimated 10-year risk of hard CHD [36]. Individuals with $<10 \%$ and $10-20 \%$ risk over the next 10 years are considered low and intermediate risk, respectively, while those with $>20 \%$ risk or existing CHD or CHD risk equivalents are considered high risk. Diseases listed by the NCEPATP III that are CHD risk equivalents include diabetes, symptomatic carotid artery disease, peripheral artery disease and abdominal aortic aneurysm [34].

The National Kidney Foundation has suggested in its Kidney Disease Outcomes Quality Initiative guidelines that CKD be considered a CHD risk equivalent, which they acknowledge is only supported by grade ' $\mathrm{B}$ ', or moderate evidence [37]. This concept of CHD risk equivalency was examined in the Atherosclerosis Risk in Communities (ARIC) study, where the presence of stage $3 \mathrm{CKD}$ did not confer the same hard CHD risk as existing CHD among adults aged 45-64 years (fig. 1) [38, 39]. In contrast, a similar study in elderly adults $>65$ years in the

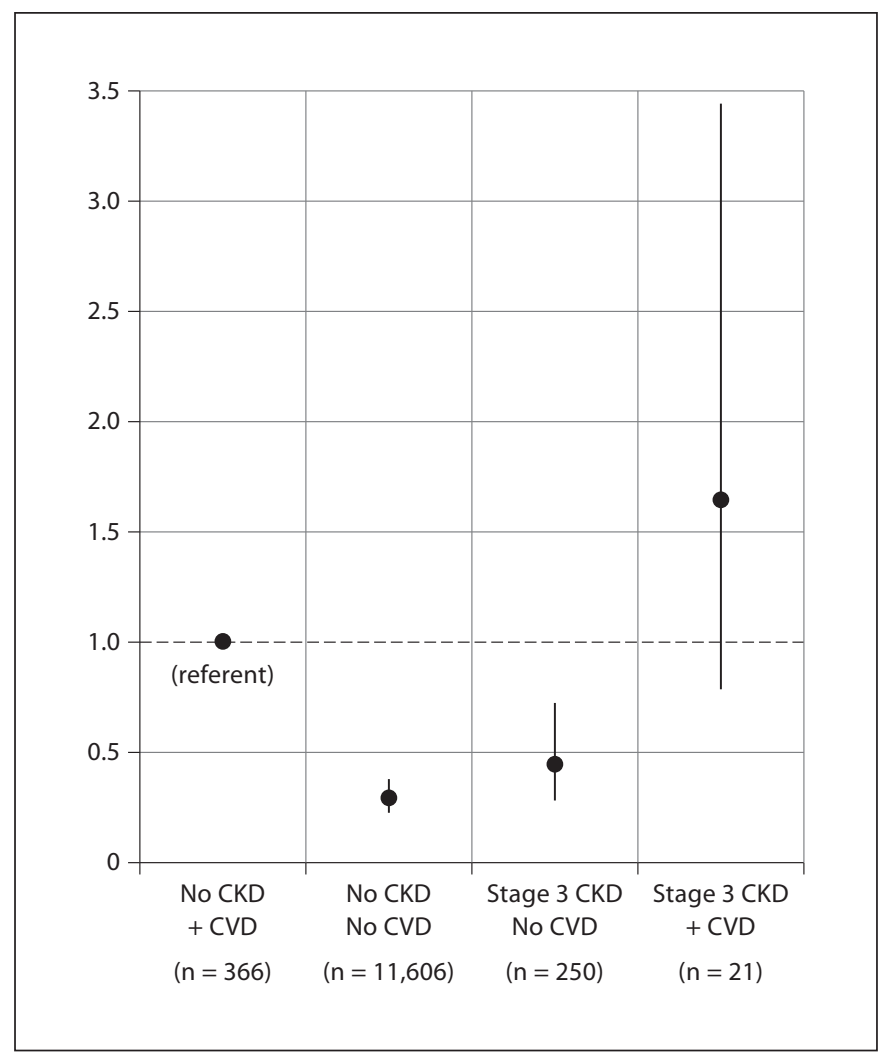

Fig. 1. Relative risk of fatal CHD or myocardial infarction by presence of stage $3 \mathrm{CKD}$ and/or CVD. Adapted from Wattanakit et al. [39].

Cardiovascular Health Study (CHS) found that CKD stage 3-4 conferred equivalent 10 -year cardiovascular mortality risk as history of MI $[38,39]$. Better classification methods accounting for both decreased GFR and increased urine albumin excretion simultaneously could help identify individuals truly at high risk for CHD events.

\section{Evaluation of a Multivariate Model}

Efforts to improve upon the existing Framingham risk score should either identify new individuals with high CVD risk or reclassify individuals into more appropriate categories. Several methods may be used to assess the performance of a risk prediction model [19, 40-42]. The area under the receiver-operating characteristic curve (AUC) measures the probability that a given individual with disease will have a higher risk prediction score than an individual without disease, termed 'discrimination'. 
Higher AUC values with the addition of a biomarker such as serum creatinine or ACR to the Framingham equation would equate to improved discrimination between individuals who do and do not develop CVD. However, to improve CVD discrimination, a biomarker must be strongly associated with CVD yet very poorly correlated with traditional CVD risk factors, including age [43-45].

Another measure of risk prediction performance is calibration, which refers to the agreement between observed and predicted outcomes. The addition of a new biomarker should improve classification of individuals as low or high CVD risk because risk management for individuals classified as intermediate risk remains controversial. The net reclassification index (NRI) assesses the difference in proportion of individuals with and without events who move to a low- or high-risk category; a significantly high NRI indicates classification improvement with the addition of the biomarker(s) [39].

\section{Framingham Risk Score and CKD}

The Framingham equation was created using data from a population-based cohort in which the majority of individuals did not have CKD. Thus, the generalizability of this equation for adults with CKD deserves scrutiny. Weiner [46] investigated the utility of the Framingham equation to predict incident MI or CHD mortality among individuals with stage 3 and 4 CKD and no pre-existing CVD utilizing data from the ARIC and CHS studies. In this study, the association between CHD events and traditional risk factors was not consistent with known associations in the general population. For example, HDL levels were not associated with CHD events. The Framingham equation demonstrated poor discrimination in men and underpredicted events in both men and women with $\mathrm{CKD}$, and this was attributed to high competing 10-year mortality risk of $35 \%$ in men and $20 \%$ in women [41].

\section{Adding eGFR, Creatinine, Cystatin C or ACR to the Framingham Equation}

Efforts to capture excess CVD risk associated with CKD have been evaluated by adding eGFR, cystatin $\mathrm{C}$ and ACR to models with traditional CVD risk factors [10, 41, 46-48]. Hallan et al. [10] investigated the use of eGFR and ACR (composite variable combining 4 categories of eGFR and ACR) to improve prediction of cardiovascular mortality in a Norwegian community-based study. There was minimal improvement in risk prediction after adding these terms to a model that included age, sex, diabetes mellitus, prevalent CVD, systolic blood pressure, cholesterol levels and smoking [49]. A similar study by Weiner et al. [50] investigated whether presence of eGFR $<60 \mathrm{ml} /$ $\mathrm{min} / 1.73 \mathrm{~m}^{2}$ improves the discrimination and calibration of the Framingham equation (based on JNC and NCEP categories) for the composite outcome of MI or fatal CAD. Although CKD was an important predictor of the composite outcome, particularly in African Americans, it did not improve discrimination of cardiac events or mortality. Another study utilized a population-based cohort of elderly men (average age 71) living in Sweden and demonstrated significant improvement in prediction of cardiovascular mortality when 4 biomarkers (troponin I, Nterminal pro-brain natriuretic peptide, cystatin $\mathrm{C}$ and $\mathrm{C}$ reactive protein) were added to traditional CVD risk factors (table 1) [41]. Cystatin C alone increased the AUC by 0.027 in the entire cohort but not when the analysis was restricted to participants without baseline CVD. Moreover, serum levels of cystatin $\mathrm{C}$ are correlated with inflammation which could confound its association with CVD and mortality [51, 52].

In collaboration with investigators from the Multiethnic Study of Atherosclerosis (MESA), we previously evaluated the addition of serum cystatin $\mathrm{C}$ and creatinine to the Framingham risk score variables to predict a wide spectrum of incident CVD events including CHD, heart failure, stroke and peripheral arterial disease in a cohort without baseline CVD [48]. No significant change in risk prediction was noted with the addition of serum cystatin $\mathrm{C}$ or creatinine to the Framingham equation. Similar to the study by Hallan et al. [10], approximately $11 \%$ of MESA participants classified as intermediate risk with the Framingham equation were reclassified as high risk with the addition of cystatin C. However, the NRI was very low $(1.6 \% ; \mathrm{p}=0.48)$ with the addition of cystatin $\mathrm{C}$ and negative with the addition of serum creatinine $(-0.9 \% ; \mathrm{p}=0.49)$.

In contrast to CKD measures, the coronary artery calcification (CAC) score improves risk stratification for individuals classified as intermediate risk with the Framingham equation [53-55]. In the MESA cohort, addition of the CAC score to the Framingham equation reclassified $23 \%$ of individuals with incident CVD events as high risk and an additional $13 \%$ without events as low risk with an overall NRI of 23\% [53]. However, CAC is not routinely measured, and its cost-effectiveness and role in improving risk prediction in populations enriched with CKD deserves additional evaluation. 
Table 1. Description of studies examining CKD measures to improve CVD risk prediction

\begin{tabular}{|c|c|c|c|c|c|c|}
\hline $\begin{array}{l}\text { Author } \\
\text { year }\end{array}$ & Population & Primary outcome & Model predictors & $\begin{array}{l}\text { Added } \\
\text { biomarkers }\end{array}$ & Original AUC & $\begin{array}{l}\text { Change in AUC } \\
\text { with biomarkers }\end{array}$ \\
\hline $\begin{array}{l}\text { Wang et al., } \\
2006[40]\end{array}$ & $\begin{array}{l}\text { Framingham } \\
\text { Offspring study }\end{array}$ & $\begin{array}{l}\text { Fatal and nonfatal MI, } \\
\text { coronary insufficiency, } \\
\text { CHF, stroke }\end{array}$ & $\begin{array}{l}\text { Age, sex, DM, smoking } \\
\text { status, BP categories, TC, } \\
\text { HDL, BMI, creatinine }\end{array}$ & ACR, BNP & 0.76 & +0.01 \\
\hline $\begin{array}{l}\text { Hallan et al., } \\
2007[10]\end{array}$ & $\begin{array}{l}\text { Population-based } \\
\text { Norwegian study }\end{array}$ & $\begin{array}{l}\text { Cardiovascular death } \\
\text { (ICD-10 codes } \\
\text { I10-I15, I20-I25, } \\
\text { I44-I49, I50, I60-I69, } \\
\text { I70-I77) }\end{array}$ & $\begin{array}{l}\text { Age, sex, DM, smoking } \\
\text { status, SBP, BP } \\
\text { medication, TC, HDL, } \\
\text { prevalent CVD }\end{array}$ & $\begin{array}{l}\text { eGFR and } \\
\text { ACR } \\
\text { categories }\end{array}$ & $\begin{array}{l}\text { Age }<70 \text { years } 0.91 \\
\text { Age } \geq 70 \text { years } 0.76\end{array}$ & $\begin{array}{l}\text { Age }<70+0.002 \\
\text { Age } \geq 70+0.01\end{array}$ \\
\hline $\begin{array}{l}\text { Olsen et al., } \\
2007[56]\end{array}$ & $\begin{array}{l}\text { Population-based } \\
\text { Danish study }\end{array}$ & $\begin{array}{l}\text { Cardiovascular death, } \\
\text { non-fatal MI, stroke }\end{array}$ & $\begin{array}{l}\text { Age, sex, DM, smoking } \\
\text { status, SBP, LDL, heart } \\
\text { rate, glucose, LVEF, prior } \\
\text { MI, prior stroke }\end{array}$ & $\begin{array}{l}\text { ACR, hsCRP, } \\
\text { NT-proBNP }\end{array}$ & 0.82 & $\begin{array}{l}+0.01 \text { (ACR) } \\
+0.02 \text { (all } 3 \\
\text { biomarkers) }\end{array}$ \\
\hline $\begin{array}{l}\text { Weiner et al., } \\
2007 \text { [46] }\end{array}$ & $\begin{array}{l}\text { Pooled from } 2 \\
\text { population-based } \\
\text { US studies, } 1 \\
\text { study with adults } \\
>65 \text { years age }\end{array}$ & $\begin{array}{l}\text { CHD death, nonfatal } \\
\text { MI }\end{array}$ & $\begin{array}{l}\text { Age, sex, DM, smoking } \\
\text { status, BP categories, TC, } \\
\text { HDL }\end{array}$ & eGFR $<60$ & $\begin{array}{l}\text { White men } 0.74 \\
\text { AA men } 0.64 \\
\text { White women } \\
0.78 \\
\text { AA women } 0.75\end{array}$ & $\begin{array}{l}\text { White men }+0.002 \\
\text { AA men }-0.002 \\
\text { White women }+0.001 \\
\text { AA women }+0.004\end{array}$ \\
\hline $\begin{array}{l}\text { Zethelius et } \\
\text { al., } 2008 \text { [41] }\end{array}$ & $\begin{array}{l}\text { Community- } \\
\text { based cohort of } \\
\text { elderly Swedish } \\
\text { men (subsample } \\
\text { without CVD) }\end{array}$ & $\begin{array}{l}\text { Cardiovascular death } \\
\text { (ICD-10 codes } \\
\text { I00-I99) }\end{array}$ & $\begin{array}{l}\text { Age, DM, smoking } \\
\text { status, SBP, BP } \\
\text { medication, TC, HDL, } \\
\text { cholesterol medication, } \\
\text { BMI }\end{array}$ & $\begin{array}{l}\text { Cystatin C, } \\
\text { troponin, } \\
\text { CRP, NT- } \\
\text { proBNP }\end{array}$ & 0.69 & $\begin{array}{l}+0.01 \text { (cystatin } \mathrm{C} \text { ) } \\
+0.06 \text { (all } 4 \\
\text { biomarkers) }\end{array}$ \\
\hline $\begin{array}{l}\text { Shlipak et al., } \\
2008 \text { [47] }\end{array}$ & $\begin{array}{l}\text { Adults with pre- } \\
\text { existing CHD }\end{array}$ & $\begin{array}{l}\text { CHD death, nonfatal } \\
\text { MI, stroke }\end{array}$ & $\begin{array}{l}\text { Age, sex, race, DM, } \\
\text { smoking status, HTN, } \\
\text { BMI, creatinine, aspirin } \\
\text { use, LVEF <50, prior MI, } \\
\text { prior stroke }\end{array}$ & $\begin{array}{l}\text { ACR, CRP, } \\
\text { NT-proBNP }\end{array}$ & 0.73 & $\begin{array}{l}+0.04 \text { (all } 3 \\
\text { biomarkers) }\end{array}$ \\
\hline $\begin{array}{l}\text { Ito et al., } \\
2010[48]\end{array}$ & $\begin{array}{l}\text { Population-based } \\
\text { multiethnic US } \\
\text { study without } \\
\text { clinical CVD }\end{array}$ & $\begin{array}{l}\text { CVD death, } \\
\text { resuscitated cardiac } \\
\text { arrest, nonfatal MI, } \\
\text { stroke, angina, PAD, } \\
\text { CHF }\end{array}$ & $\begin{array}{l}\text { Age, sex, DM, smoking } \\
\text { status, SBP, BP } \\
\text { medication, TC, HDL, } \\
\text { cholesterol medication, } \\
\text { BMI }\end{array}$ & $\begin{array}{l}\text { Creatinine or } \\
\text { cystatin C }\end{array}$ & 0.72 & $\begin{array}{l}-0.01 \text { (creatinine) } \\
+0.02(\text { cystatin } C)\end{array}$ \\
\hline
\end{tabular}

$\mathrm{DM}=$ Diabetes mellitus; $\mathrm{TC}=$ total cholesterol; $\mathrm{HDL}=$ high-density cholesterol $\mathrm{LDL}=$ low-density cholesterol; $\mathrm{BMI}=$ body mass index; $\mathrm{BNP}=$ brain natriuretic peptide; $\mathrm{PAD}$ = peripheral arterial disease; $\mathrm{CHF}=$ congestive heart failure; $\mathrm{ICD}=$ International Statistical Classification of $\mathrm{Diseases}$ : LVEF = left ventricular ejection fraction; hsCRP $=$ high-sensitivity $\mathrm{C}$-reactive protein; NT-proBNP $=\mathrm{N}$-terminal pro-brain natriuretic peptide.

\section{Conclusion}

Increased ACR or decreased eGFR is associated with higher CVD risk, yet the presence of traditional CVD risk factors does not entirely account for this excess risk. The Framingham equation underpredicts CVD risk in adults with CKD. However, incorporation of CKD markers such as eGFR, serum creatinine, cystatin $\mathrm{C}$ and ACR have so far shown minimal improvement in CVD risk discrimination. Future studies should evaluate CVD risk equations that account for the unique comorbidities associated with CKD in addition to traditional CVD risk factors.
References

Nephron Clin Pract 2011;119:c171-c178 705-711.
1 Coresh J, Selvin E, Stevens LA, et al: Prevalence of chronic kidney disease in the United States. JAMA 2007;298:2038-2047.

-2 Shlipak MG, Fried LF, Cushman M, et al: Cardiovascular mortality risk in chronic kidney disease: comparison of traditional and novel risk factors. JAMA 2005;293:1737-1745.

-3 Shlipak MG, Simon JA, Grady D, et al: Renal insufficiency and cardiovascular events in postmenopausal women with coronary heart disease. J Am Coll Cardiol 2001;38:

4 Muntner P, He J, Hamm L, Loria C, Whelton PK: Renal insufficiency and subsequent death resulting from cardiovascular disease in the United States. J Am Soc Nephrol 2002; 13:745-753. 
5 Sarnak MJ, Levey AS, Schoolwerth AC, et al: Kidney disease as a risk factor for development of cardiovascular disease: a statement from the American Heart Association Councils on Kidney in Cardiovascular Disease, High Blood Pressure Research, Clinical Cardiology, and Epidemiology and Prevention. Hypertension 2003;42:1050-1065.

-6 Weiner DE, Krassilnikova M, Tighiouart H, Salem DN, Levey AS, Sarnak MJ: CKD classification based on estimated GFR over three years and subsequent cardiac and mortality outcomes: a cohort study. BMC Nephrol 2009; 10:26.

7 Manjunath G, Tighiouart H, Coresh J, et al: Level of kidney function as a risk factor for cardiovascular outcomes in the elderly. Kidney Int 2003;63:1121-1129.

$>8$ Manjunath G, Tighiouart H, Ibrahim H, et al: Level of kidney function as a risk factor for atherosclerotic cardiovascular outcomes in the community. J Am Coll Cardiol 2003; 41:47-55.

-9 Parikh NI, Hwang SJ, Larson MG, Levy D, Fox CS: Chronic kidney disease as a predictor of cardiovascular disease (from the Framingham Heart Study). Am J Cardiol 2008;102:47-53.

10 Hallan S, Astor B, Romundstad S, Aasarod K, Kvenild K, Coresh J: Association of kidney function and albuminuria with cardiovascular mortality in older vs. younger individuals: the HUNT II study. Arch Intern Med 2007;167:2490-2496.

$\checkmark 11$ Go AS, Chertow GM, Fan D, McCulloch CE, Hsu CY: Chronic kidney disease and the risks of death, cardiovascular events, and hospitalization. N Engl J Med 2004;351: 1296-1305.

-12 Chronic Kidney Disease Prognosis Consortium, Matsushita K, van der Velde M, et al: Association of estimated glomerular filtration rate and albuminuria with all-cause and cardiovascular mortality in general population cohorts: a collaborative meta-analysis. Lancet 2010;375:2073-2081.

13 Warnock DG, Muntner P, McCullough PA, et al: Kidney function, albuminuria, and allcause mortality in the REGARDS (reasons for geographic and racial differences in stroke) study. Am J Kidney Dis 2010;56:861871.

14 Arnlov J, Evans JC, Meigs JB, et al: Lowgrade albuminuria and incidence of cardiovascular disease events in nonhypertensive and nondiabetic individuals: the Framingham Heart Study. Circulation 2005;112:969975.

15 Gerstein HC, Mann JF, Yi Q, et al: Albuminuria and risk of cardiovascular events, death, and heart failure in diabetic and non-diabetic individuals. JAMA 2001;286:421-426.

-16 Hemmelgarn BR, Manns BJ, Lloyd A, et al: Relation between kidney function, proteinuria, and adverse outcomes. JAMA 2010;303: 423-429.
17 Oterdoom LH, Gansevoort RT, Schouten JP, de Jong PE, Gans RO, Bakker SJ: Urinary creatinine excretion, an indirect measure of muscle mass, is an independent predictor of cardiovascular disease and mortality in the general population. Atherosclerosis 2009; 207:534-540.

-18 D’Agostino RB S, Grundy S, Sullivan LM, Wilson P, CHD Risk Prediction Group: Validation of the Framingham coronary heart disease prediction scores: results of a multiple ethnic groups investigation. JAMA 2001; 286:180-187.

19 Lloyd-Jones DM, Liu K, Tian L, Greenland P. Narrative review: assessment of C-reactive protein in risk prediction for cardiovascular disease. Ann Intern Med 2006;145:35-42.

20 Wilson PW, D'Agostino RB, Levy D, Belanger AM, Silbershatz H, Kannel WB: Prediction of coronary heart disease using risk factor categories. Circulation 1998;97:18371847.

21 Anderson RJ, O’brien M, MaWhinney S, et al: Renal failure predisposes patients to adverse outcome after coronary artery bypass surgery. VA cooperative study \#5. Kidney Int 1999;55:1057-1062.

22 Beddhu S, Allen-Brady K, Cheung AK, et al: Impact of renal failure on the risk of myocardial infarction and death. Kidney Int 2002; 62:1776-1783.

23 Mann JF, Gerstein HC, Pogue J, Bosch J, Yusuf S: Renal insufficiency as a predictor of cardiovascular outcomes and the impact of ramipril: the HOPE randomized trial. Ann Intern Med 2001;134:629-636.

24 Weiner DE, Tighiouart H, Amin MG, et al: Chronic kidney disease as a risk factor for cardiovascular disease and all-cause mortality: a pooled analysis of community-based studies. J Am Soc Nephrol 2004;15:13071315.

25 National kidney foundation: K/DOQI clinical practice guidelines for chronic kidney disease: evaluation, classification and stratification. Am J Kidney Dis 2002;39:S46-S64.

26 Kramer H, Jacobs DR, Jr, Bild D, et al: Urine albumin excretion and subclinical cardiovascular disease. The Multi-Ethnic Study of Atherosclerosis. Hypertension 2005;46:3843.

-27 Foley RN, Parfrey PS, Harnett JD, et al: Clinical and echocardiographic disease in patients starting end-stage renal disease therapy. Kidney Int 1995;47:186-192.

28 Levin A, Singer J, Thompson CR, Ross H, Lewis M: Prevalent left ventricular hypertrophy in the predialysis population: Identifying opportunities for intervention. Am J Kidney Dis 1996;27:347-354.

29 Go AS, Yang J, Ackerson LM, et al: Hemoglobin level, chronic kidney disease, and the risks of death and hospitalization in adults with chronic heart failure: the Anemia in Chronic Heart Failure: Outcomes and Resource Utilization (ANCHOR) study. Circulation 2006;113:2713-2723.
30 Gutierrez OM, Januzzi JL, Isakova T, et al: Fibroblast growth factor 23 and left ventricular hypertrophy in chronic kidney disease. Circulation 2009; 119:2545-2552.

31 Thorp ML, Johnson ES, Yang X, Petrik AF, Platt R, Smith DH: Effect of anaemia on mortality, cardiovascular hospitalizations and end-stage renal disease among patients with chronic kidney disease. Nephrology (Carlton) $2009 ; 14: 240-246$.

$>32$ Wolf M, Shah A, Gutierrez O, et al: Vitamin $\mathrm{D}$ levels and early mortality among incident hemodialysis patients. Kidney Int 2007;72: 1004-1013.

33 Smith DH, Johnson ES, Thorp ML, Petrik A, Yang X, Blough DK: Outcomes predicted by phosphorous in chronic kidney disease: a retrospective CKD-inception cohort study. Nephrol Dial Transplant 2010;25:166-174.

-34 Kannel WB, Feinleib M, McNamara PM, Garrison RJ, Castelli WP: An investigation of coronary heart disease in families. The Framingham Offspring Study. Am J Epidemiol 1979;110:281-290.

35 Coresh J, Byrd-Holt D, Astor BC, et al: Chronic kidney disease awareness, prevalence, and trends among US adults, 1999 to 2000. J Am Soc Nephrol 2005;16:180-188.

36 National Cholesterol Education Program (NCEP) Expert Panel on Detection, Evaluation, and Treatment of High Blood Cholesterol in Adults (Adult Treatment Panel III). Third report of the National Cholesterol Education Program (NCEP) Expert Panel on Detection, Evaluation, and Treatment of High Blood Cholesterol in Adults (adult treatment panel III) final report. Circulation 2002; 106:3143-3421.

37 National Kidney Foundation: K/DOQI clinical practice guidelines for managing dyslipidemias in chronic kidney disease. Am J Kidney Dis 2003;41(suppl 3):S1-S152.

38 Hyre AD, Fox CS, Astor BC, Cohen AJ, Muntner P: The impact of reclassifying moderate CKD as a coronary heart disease risk equivalent on the number of US adults recommended lipid-lowering treatment. Am J Kidney Dis 2007;49:37-45.

-39 Wattanakit K, Coresh J, Muntner P, Marsh J, Folsom AR: Cardiovascular risk among adults with chronic kidney disease, with or without prior myocardial infarction. J Am Coll Cardiol 2006;48:1183-1189.

-40 Wang TJ, Gona P, Larson MG, et al: Multiple biomarkers for the prediction of first major cardiovascular events and death. N Engl J Med 2006;355:2631-2639.

41 Zethelius B, Berglund L, Sundstrom J, et al: Use of multiple biomarkers to improve the prediction of death from cardiovascular causes. N Engl J Med 2008;358:2107-2116.

42 Kim HC, Greenland P, Rossouw JE, et al: Multimarker prediction of coronary heart disease risk: the Women's Health Initiative. J Am Coll Cardiol 2010;55:2080-2091. 
43 Steyerberg EW, Vickers AJ, Cook NR, et al: Assessing the performance of prediction models: a framework for traditional and novel measures. Epidemiology 2010;21:128-138.

-44 Pencina MJ, D’Agostino RB S, D’Agostino RB, Jr, Vasan RS: Evaluating the added predictive ability of a new marker: from area under the ROC curve to reclassification and beyond. Stat Med 2008;27:157-172; discussion 207-212.

45 Lloyd-Jones DM, Tian L: Predicting cardiovascular risk: so what do we do now? Arch Intern Med 2006;166:1342-1344.

46 Weiner DE, Tighiouart H, Elsayed EF, et al: The Framingham predictive instrument in chronic kidney disease. J Am Coll Cardiol 2007;50:217-224.

47 Shlipak MG, Ix JH, Bibbins-Domingo K, Lin F, Whooley MA: Biomarkers to predict recurrent cardiovascular disease: the Heart and Soul study. Am J Med 2008;121:50-57.

48 Ito $\mathrm{H}$, Pacold I, Durazo R, et al: The effect of including cystatin $\mathrm{C}$ or creatinine in cardiovascular risk model for asymptomatic individuals. The Multi-Ethnic Study of Atherosclerosis. Circulation 2010;122:A8982.
49 De Backer G, Ambrosioni E, Borch-Johnsen $\mathrm{K}$, et al: European guidelines on cardiovascular disease prevention in clinical practice. Third Joint Task Force of European and Other Societies on Cardiovascular Disease Prevention in Clinical Practice (constituted by representatives of eight societies and by invited experts). Atherosclerosis 2004;173. 381-391.

50 Weiner DE, Tighiouart H, Griffith JL, et al: Kidney disease, Framingham risk scores, and cardiac and mortality outcomes. Am J Med 2007;120:552.e1-552.e8.

51 Keller C, Katz R, Cushman M, Fried LF, Shlipak M: Association of kidney function with inflammatory and procoagulant markers in a diverse cohort: a cross-sectional analysis from the Multi-Ethnic Study of Atherosclerosis (MESA). BMC Nephrol 2008;9:9.

>52 Knight EL, Verhave JC, Spiegelman D, et al: Factors influencing serum cystatin $\mathrm{C}$ levels other than renal function and the impact on renal function measurement. Kidney Int 2004;65:1416-1421
53 Folsom AR, Kronmal RA, Detrano RC, et al: Coronary artery calcification compared with carotid intima-media thickness in the prediction of cardiovascular disease incidence: the Multi-Ethnic Study of Atherosclerosis (MESA). Arch Intern Med 2008;168: 1333-1339.

54 Greenland P, LaBree L, Azen SP, Doherty TM, Detrano RC: Coronary artery calcium score combined with Framingham score for risk prediction in asymptomatic individuals. JAMA 2004;291:210-215.

55 Polonsky TS, McClelland RL, Jorgensen NW, et al: Coronary artery calcium score and risk classification for coronary heart disease prediction. JAMA 2010;303:1610-1616.

-56 Olsen MH, Hansen TW, Christensen MK, Gustafsson F, Rasmussen S, Wachtell K, Ibsen H, Torp-Pedersen C, Hildebrandt PR: $\mathrm{N}$-terminal pro-brain natriuretic peptide, but not high sensitivity C-reactive protein, improves cardiovascular risk prediction in the general population. Eur Heart J 2007; 28:1374-1381

\title{
Editorial Comment
}

\author{
Meguid El Nahas, Sheffield
}

The mini review by Chang and Kramer addresses the taxing issue of prediction of CVD in CKD patients. A rising number of reports confirm the high morbidity and mortality risks associated with albuminuria and low eGFR. This has led some to advocate universal screening of communities for these renal-related variables in an attempt to identify those at higher risk of CVD mortality as well as all-cause mortality. Others, including myself, feel that microalbuminuria and reduced eGFR in the community are a reflection of ageing and underlying CVD. With that in mind, it is not too surprising that $\mathrm{CKD}$, as a manifestation of underlying CVD, predicts CVD outcomes! So the logical task within the community would be to focus on the prevention of CVD to prevent $\mathrm{CKD}$; protect your heart to protect your kidneys! This is all the more relevant since recent reports from the Global Burden of Metabolic Risk Factors of the Chronic Diseases Collaborating Group point to the fact that obesity, diabetes, hypertension, dyslipidemia and smoking are on the increase worldwide [1-3].

This will undoubtedly be associated, over the next decade, with a rising number of CKD in the older individuals; the bulk of those suffering from CKD in the commu- nity are over 60. Emphasis should therefore be on the early detection of those at risk of CVD within the community. Addressing and minimizing their risk factors may in turn reduce the incidence of CKD. There are a number of prediction tools to identify those at increased CVD risk, including the Framingham Risk Score. Unfortunately, current prediction tools, including Framingham Risk Score, perform poorly in CKD patients. The review by Chang and Kramer shows that adding albuminuria, cystatin C or eGFR to conventional risk scores adds little to their predictability and showed minimal improvement in CVD risk discrimination. It concludes that future studies should evaluate CVD risk equations that account for the unique comorbidities associated with CKD in addition to traditional CVD risk factors. Perhaps, one major renal-related risk factor that seems to be overlooked is anemia! This could be the case in spite of a number of studies pointing to its major impact on CVD outcomes in CKD patients [4] as well as its negative impact on CKD progression in those with underlying CVD [5]. Perhaps a CVD risk prediction equation incorporating hemoglobin level may be all that is needed? 


\section{References}

- Finucane MM, Stevens GA, Cowan MJ, Danaei G, Lin JK, Paciorek CJ, Singh GM, Gutierrez HR, Lu Y, Bahalim AN, Farzadfar F, Riley LM, Ezzati M, Global Burden of Metabolic Risk Factors of Chronic Diseases Collaborating Group (Body Mass Index): National, regional, and global trends in body-mass index since 1980: systematic analysis of health examination surveys and epidemiological studies with 960 country-years and 9.1 million participants. Lancet 2011;377:557-567.

2 Danaei G, Finucane MM, Lin JK, Singh GM, Paciorek CJ, Cowan MJ, Farzadfar F, Stevens GA, Lim SS, Riley LM, Ezzati M, Global Burden of Metabolic Risk Factors of Chronic Diseases Collaborating Group (Blood Pressure): National, regional, and global trends in systolic blood pressure since 1980: systematic analysis of health examination surveys and epidemiological studies with 786 country-years and 5.4 million participants. Lancet 2011;377:568-577.

Farzadfar F, Finucane MM, Danaei G, Pelizzari PM, Cowan MJ, Paciorek CJ, Singh GM, Lin JK, Stevens GA, Riley LM, Ezzati M, Global Burden of Metabolic Risk Factors of Chronic Diseases Collaborating Group (Cholesterol): National, regional, and global trends in serum total cholesterol since 1980: systematic analysis of health examination surveys and epidemiological studies with 321 country-years and 3.0 million participants. Lancet 2011;377:578-586.

Vlagopoulos PT, Tighiouart H, Weiner DE, Griffith J, Pettitt D, Salem DN, Levey AS, Sarnak MJ: Anemia as a risk factor for cardiovascular disease and all-cause mortality in diabetes: the impact of chronic kidney disease. J Am Soc Nephrol 2005;16:3403-3410.

5 Bansal N, Tighiouart H, Weiner D, Griffith J, Vlagopoulos P, Salem D, Levin A, Sarnak MJ: Anemia as a risk factor for kidney function decline in individuals with heart failure. Am J Cardiol 2007;99:1137-1142. 